\title{
Editorial
}

Theodore Powers, Jeremy Rayner*

\section{Pathogenic Politics: Authoritarianism, Inequality, and Capitalism in the COVID-19 Crisis}

https://doi.org/10.1515/opan-2020-0113

received June 28, 2021; accepted July 12, 2021.

\begin{abstract}
We provide an introduction to this special issue on the politics of the COVID-19 pandemic, presenting some of the key findings and central arguments of the articles collected herein, and discussing their significance in relation to the broader political context of the pandemic. We address the roles of necropolitics and "necrosecurity", pointing to their relationships to colonial and eugenicist histories, as well as some of the ways in which a globally-ascendant authoritarian populism contributed to the often-disastrous mismanagement of the pandemic. We consider how unequal structures of social and public obligation were reproduced to the detriment of lives and livelihoods, and the challenges facing institutions of protection, care, and social reproduction. Finally, we consider some of the ways in which the pandemic may have opened up avenues for more systemic transformations-for good or for ill.
\end{abstract}

Keywords: Covid-19; social inequality; politics of pandemics; public health; medical anthropology.

\section{Introduction}

This collection addresses the COVID-19 pandemic, with a focus on its local contours, the wide-ranging social effects that it has produced, the policy processes that have unfolded alongside it, and the political dynamics that presaged it and shaped its progression. For most, the COVID-19 pandemic was an unexpected shock, disrupting everyday life in ways that were previously unimaginable. But what initially may have appeared as a radical restructuring of social dynamics across the world has instead taken on an altogether different character. As the articles gathered in this collection highlight, the COVID-19 pandemic has built upon-and perhaps accelerated-existing social processes, radically altering the organization of everyday life, but in ways that reflected pre-pandemic relations of power, inequality, and exploitation.

Informed by the deepening of existing dynamics of inequality, violence, and material deprivation over the course of the first year of the COVID-19 pandemic, this collection focuses on the ways in which political processes inform the emergence, progression, and responses to an infectious disease epidemic. In doing so, this collection adds to two initiatives by medical anthropologists that have produced critical insights on the COVID-19 pandemic. Building on a series of contributions framed as "Rapid Responses", Adams and Nading (2020) oversaw the develop of a collection of articles that analyzes the depth and breadth of contributions from medical anthropologists on the COVID-19 pandemic. Following a similar path, Lynteris (2020) coordinated the development of an online forum that gathered perspectives from 17 anthropologists and historians to analyze the COVID-19 pandemic alongside other epidemics and related disease control interventions. Informed by these collections, this special issue analyzes the differential courses of the virus in distinct contexts, revealing the centrality of political and social formations to the course of the pandemic.

Article note: This article is a part of the Special Issue on Pathogenic Politics: Life, Death, and Social Responses to the COVID-19 Pandemic, edited by Theodore Powers \& Jeremy Rayner.

\footnotetext{
${ }^{\star}$ Corresponding author: Jeremy Rayner, Laboratory on Food, Work, Migration and Development, Department of Political and Social Sciences, Università della Calabria, Arcavacata di Rende 87036, Cosenza, Italy, E-mail: jrayner@gradcenter.cuny.edu

Theodore Powers, Department of Anthropology, University of lowa, lowa City, 52245, lowa, United States
} 
The thematic focus of this issue is on the politics of the pandemic, considered in a broad sense of the processes through which power is reproduced and contested in and around the state, viewed through an anthropological lens attentive, on the one hand, to the grounded realities of "everyday life", and on the other, to the production of meaning through both discourses and practices. The articles gathered here attend to both the struggles that shaped the course and consequences of the pandemic and the pandemic's effects on the distribution of power and resources. In doing so, this collection is animated by a concern with how power and politics actively contribute to the emergence-and severity-of infectious disease epidemics. We start from Paul Farmer's (1999) framing of the "pathologies of power": that it is social and economic inequalities that inform how epidemics of disease and violence unfold. The articles here build on Farmer's insight by focusing on the ways that modalities of political power have informed how the COVID-19 pandemic has unfolded, including the measures taken-or not taken-by states to control the disease, as well as the effects of these measures on lives, livelihoods, and unequal social relations.

A central question that emerges from the pandemic, when considered politically, is the extent to which it deepened existing inequalities, or, on the contrary, provided new grounds to alter or upend them. In assessing this pathogen's effects and the historical moment in which it erupted, the articles gathered for this collection focus on the particular social and historical conditions within which COVID-19 took hold, while also accounting for broader patterns of inequality and violence. COVID-19 emerged in a world characterized by a resurgent ethnonationalist "populist" right that transcended the north/south divide and marked an ongoing crisis of liberal democracy, most notably in its traditional heartlands, and a global economy showing signs of "secular stagnation"-again, especially in its historic centers, the United States, Europe and Japan (Rayner et al., 2020). The world into which the pandemic emerged was also characterized by the increasing prominence of a digital or cognitive capitalism, developed around the universal surveillance of daily life (Zuboff, 2019), which has also tended to transform the public sphere in unexpected ways, sidelining traditional gatekeepers while fomenting sensational, paranoid and conspiratorial discourses, often to the detriment of public health messaging.

The articles collected here consider the pandemic in this context, using ethnography and the study of public culture to assess how the power relations of the contemporary moment have shaped and, perhaps, been altered by, the pandemic's course. The eight research articles that constitute this special issue analyze the impact of the COVID19 pandemic and the social responses to it in the United States, Peru, the Philippines, Ecuador, and South Africa. Building on the pandemic's transgression of artificial divisions-including the divide between northern and southern hemispheres-we present these case studies to provoke broader conversations on continuity and connection. As humanity faces a series of concurrent and lethal crises, we consider that responses to the COVID-19 pandemic offer insights into a contingent future that carries both possibilities and dangers.

\section{Biosecurity, Citizenship, and Necropolitics}

A theme that cuts across the articles contributed to this collection is the state's role in social processes that contribute to-or actively produce-death. Examining the emergence and political responses to the COVID-19 pandemic in the United States, Martha Lincoln builds on anthropological debates surrounding biosecurity and necropolitics to propose the concept of "necrosecurity". Critically engaging with the discourse of the Trump administration and other US political figures, Lincoln highlights how these responses to COVID-19 rationalize the sacrifice of some segments of the population-the old and those who carry other risk factors-in order to protect the health of those deemed worthy of saving: the young and fit. This immunosupremacist logic demands that some are sacrificed to secure the wellbeing of others.

Taking a historical approach to these questions, Theodore Powers builds on Arundhati Roy's (2020) conception of the COVID-19 pandemic as "a portal, a gateway between one world and the next," to assess the South African response. Analyzing the continued deployment of lethal state violence towards the country's poor Black majority during the contemporary era, Powers looks to the past to understand the roots of the post-apartheid state's necropolitical tendencies. Examining the state response to COVID-19 alongside an analysis of public health measures taken towards bubonic plague outbreaks during the colonial era, the author identifies both political and economic continuities that connect the era of imperial polities to the present. In doing so, Powers invites the reader to more fully contextualize 
neoliberal political and economic norms in the imperial context from which they were derived in assessing the dynamics of citizenship and necropolitical state violence in post-apartheid South Africa.

These papers underscore that the modern state's development of the means of deadly force has shaped the response to infectious disease outbreaks, demonstrating clear continuities between contemporary necropolitical state policies, imperial violence, and colonial eugenics.

\section{Populism, Public Health, and Authoritarian Politics}

Contemporary applications of biopolitics, necropolitics and necrosecurity are also bound up with a broader process of emergent authoritarian and populist politics. The COVID-19 pandemic emerged in the wake of the global ascendency of what has come to be known as "right-wing populism", a loose family of political movements broadly marked by charismatic leadership, rhetorical opposition to so-called "elites", and an authoritarian defense of "order" and "traditional" hierarchies of gender, ethnicity, race, national identity, as well as the prerogative of extractive capitalism over non-human nature (see Gandesha, 2020; Maskovsky \& Bjork-James, 2019; Rayner et al., 2020). Authoritarianism in this sense is not the same as an expansive state with a capillary presence throughout the social order, despite the tendency of the liberal tradition to conflate the two. Rather, authoritarianism here is understood as the emphasis on the need for the forceful maintenance of order and hierarchy. Relative to the analyses put forward in this collection, it is in fact the synthesis of this authoritarian impulse with a liberal commitment to "personal freedom", understood in a most reductive sense of the freedom to engage in commercial transactions, that proved most deadly.

The United States, which played a leading role in formulating right-wing authoritarian responses to the pandemic, serves as the focus for two papers in the collection. William Westermeyer analyzes the historical continuities between the Tea Party movement and the discursive shifts that have occurred around "reopen" protests during the pandemic. The COVID-19 pandemic highlights how the cultural world of right-wing populism has shifted in the United States as the patriotic Tea Party displays of a decade ago re-emerged and combined with the more aggressive political rhetoric of (now former) U.S. President Donald Trump in the context of pandemic protests. In examining this shift, Westermeyer illustrates both the continuities and shifts in "fundamentalist populism", including the process through which opponents are vilified, systematic mistrust of institutions is created, and certain individual rights and personal freedoms are emphasized over collective responsibilities. As the author underscores, these dynamics had clear effects on the public health response to COVID-19 in the U.S., aiding and abetting the spread of a deadly pathogen.

Kristin Hedges and Gideon Lasco also engage the role of populist discourse in the COVID-19 response, via a comparative analysis of the Philippines and the United States. The authors build on the biocommunicability approach to analyze how COVID-19 testing has been politicized in the two countries. Their focus rests on how political actors in both contexts deploy populist rhetoric to frame COVID-19 testing in ways that simplify and spectacularize the crisis while also deepening political divisions. Here, it is critical to note that the knowledge claims invoked by these populist leaders play a central role in how public understandings of COVID-19 testing have been constructed. Critically, the authors note that the invocation of these populist styles had the effect of blunting the uptake of testing, severely limiting one of the few tools available for epidemic control during the first year of the COVID-19 pandemic.

\section{Asymmetrical Obligations, Inequality and Mortality}

Much of the right-wing populist response to the pandemic was pitched as a rejection of allegedly onerous and illegitimate obligations, including some that were certainly burdensome, like remaining at home, and others that were manifestly trivial, such as mask wearing in public. As Jeremy Rayner points out in his article for this issue, one of the more notable features of the pandemic is the way that it created new public obligations that then became the subjects of public controversies. Troublingly, however, this process does not seem to have led to a widespread renegotiation of the inequalities created and sustained by existing forms of obligation, such as debt, labor, and taxation. Taking up a series of controversies through the lens of "public obligation" Rayner analyzes how the response to COVID-19 in Ecuador reaffirmed existing economic and social inequalities of class, race, and gender at the expense of popular lives and 
livelihoods. In a stark reminder of the power of financial institutions in the neoliberal global economy, the Ecuadorian government repaid bondholders rather than allocate these resources to COVID-19 preparation, contributing to one of the world's deadliest outbreaks in the city of Guayaquil. And rather than a more just redistribution of social obligations in a life-and-death situation, the response to the pandemic further eroded the precarious socio-economic position of the working class and poor, particularly those who secured a living through the informal sector. This state response paralleled the constrained critique and reaffirmation of systemic inequalities through public culture.

Luis Alberto Suárez Rojas also explores how the obligations of lockdown reaffirmed and exacerbated existing inequalities, focusing on the impact of the "hammer" of quarantine deployed by the Peruvian government in response to the COVID-19 impact. Based on extensive survey research in low-income neighborhoods in the city of Lima, the author examines how the financial effects of mobility restrictions affected the ability of those working in the informal sector to secure livelihoods, which undermined the efficacy of the apparently strict quarantine (the so-called "Peruvian paradox"). Further, Suárez Rojas underscores how subsidies provided by the state to alleviate the impact of mobility restrictions in fact benefitted large corporate conglomerates and individuals with access to the formal financial sector. As the author highlights, these measures did not reach many of those working in the informal sector, where they were most needed. At the household level, Suárez Rojas finds that the increased labor necessitated by biosecurity measures have primarily impacted women, deepening gender inequality in the context of Peru.

As these contributions highlight, existing structures of social inequality appear to have been consolidated and intensified during the pandemic in ways that ensure the distribution of the burdens of the pandemic onto the shoulders of those least able to bear them. Change in this sense has meant the intensification of existing forms of inequality and socially-produced suffering, a dynamic that has concentrated the impact of the COVID-19 pandemic in ways that reinforce gender, class and racial inequality and the uneven exposure to this deadly pathogen.

\section{Education: Disruption and Continuity in Neoliberal Social Reproduction}

A closely-related set of issues raised in this collection concern the impact of the COVID-19 pandemic in the sphere of education. Two articles in this collection address an important set of questions regarding how disruptions to in-person instruction intersected with expectations about the life course as well as the hopes and demands placed on education in the context of social and class reproduction, specifically in the United States.

Matthew Chrisler examines the impact of COVID-19 on education in Phoenix, Arizona, grappling with the ways that the political responses to the pandemic built upon neoliberal education policies and exacerbated existing barriers to education. Drawing on Stuart Hall, Chrisler employs the concept of "managed dissensus" to analyze how a conservative political alliance navigated public health concerns and political opposition to further privatize education and "reopen" the economy. Alongside this process, the author analyzes how online learning created new frontiers for the production of inequality, alienation, and disengagement, while a politically-produced moral panic served to reinforce existing dynamics of inequality and create new avenues for further disenfranchisement.

Kate Fischer and her undergraduate co-authors, Malika Rakhmonova and Mike Tran, show how the pandemic provoked fears of missing out on the "college experience", which has been socially constructed as a special time of socialization and self-creation, both desired in itself and viewed as a central moment in a successful middle-class life trajectory. This has only become more intense as neoliberalization has increased both the cost of college education and the stakes of not becoming college-educated, while universities have aggressively marketed the college experience to justify rapidly-rising tuition costs (Webb, 2019). On the one hand, this testimony highlights a particular pandemic experience, an often-overlooked set of psychological, social and economic burdens of a relatively privileged (but by no means generally secure) group, revealing the many and diverse forms of distress that the pandemic has caused. On the other hand, the analysis of this particular, exceptional conjuncture also throws into sharp relief many of the very particular and intense expectations and burdens that have been placed on higher education, even in "normal" times. 


\section{Overlapping Crises and Emergent Futures}

By the beginning of March 2020, it was clear that the pandemic was going to present an exceptional historical moment, in the fullest sense of the term, with consequent entailments for the expansion of claims, sovereign and/or popular. And as with any exceptional moment, the pandemic appeared to open up possibilities for widespread changes, with the direction and consequences hard to foretell from the outset, given the suspension of the normal determinants of politics. Stoked by resurgent right-wing authoritarian populisms of the preceding years, much of popular culture was consumed with conspiracy theories such as attributing the pandemic to foreign geopolitical rivals or a power grab by the "deep state", as discussed by Westermeyer in this issue. Speculation from critical theorists ranged from Giorgio Agamben's (2020) warnings that lock-down would bring another movement to sacrifice "full life" in the service of "bare life" (while showing striking indifference to the threat of mass death), to Slavoj Žižek's (2020) suggestion of the imminent arrival of real communism. Some progressive economists emphasized, in more measured terms, the opportunity to re-found capitalism on a more humane basis (Mazzucato, 2020).

For now, however, there are relatively few signs of radical change in any of these directions. Massive intervention by central banks, especially the US Federal Reserve, and national governments seem to have successfully shored up the system of financialized capitalism, protecting it from the destabilization that it confronted at the beginning of the pandemic, without ceding much to working class interests. Some authoritarian governments have managed to utilize the pandemic to extend their powers, for example Orbán in Hungary. Widespread surveillance and disciplinary control have arguably been further naturalized, and China in particular has seen an increase in the legitimacy of its illiberal and statist ("socialist") model. On the other hand, the political fortunes of right-wing authoritarian populism of the Trump-Bolsonaro style seem to be in recession, while the summer of 2020 saw one of the largest protest movements in the history of the United States mobilized against police violence. The articles in this issue provide a range of insights into these varied and contradictory movements, while exposing some of the more basic processes of power that underlie them.

The uneven impact of COVID-19 has, however, challenged outmoded Eurocentric narratives of modernity while raising further questions about the future of capitalism, liberal democracy and the biopolitical formation known as the modern state. Among the worst affected during the first year of the COVID-19 pandemic have been nations of the Americas-including the United States-where underdeveloped health and welfare systems were overwhelmed, even as political leaders and public intellectuals engaged in systematic denial and distortion of basic realities of the virus. The United States is a particularly striking example in this regard, as a society long seen as a bastion of modernity, development, and global biosecurity leadership visibly failed to control the emergent epidemic. In the U.S. response, the contradictions between private wealth and public penury, and between advanced scientific knowledge and mass misinformation, have been particularly acute-although it should be noted that the USA's largely state-led vaccine development program has given it relative success in this crucial area, in contrast to Europe's more free-market approach (Apuzzo, Gebrekidan, \& Pronczuk, 2021). In both cases, the expectation that wealthier nations would be able to control infectious disease outbreaks has been shattered, reorienting the focus of global health interventions to societies that often characterize major global epidemics as originating from-and languishing within-the global South.

Consolidating the inversion of Western tropes of modernity-and expectations for infectious disease outbreaks in particular-East and South-East Asian states including China, Vietnam, Taiwan and South Korea demonstrated remarkable capacities to control the spread of the SARS-CoV-2 virus, through widespread surveillance and strict, if targeted, lockdowns, greatly limiting both the public health and economic impacts of the pandemic (despite some early-if crucial-failures in China's response). With a few exceptions such as New Zealand, Western social democracies were on the whole far less successful in containing the virus's spread-and demonstrated surprising shortcomings in vaccine distribution-but were able to limit the impact on lives and livelihoods by providing access to health care, job guarantees, and other measures.

Reductive analyses that pit Asian "authoritarianism" or "Confucianism" against "Western liberalism" and "individualism" are, however, certainly inadequate (which does not mean that they will not become politically significant). While some of Asia's successes in control of the pandemic may be attributed to forms of biopolitical power that sit uneasily with some established Western conceptions of liberty-including some forms of surveillance and strict, if temporary, controls over mobility-the difference between "Eastern" and "Western" responses seems to have hinged on the development of infrastructural capacities specifically devoted to the control of pathogens in much of Asia in the 
wake of the SARS, HN1N1, and MERS outbreaks (Buckley, 2021; Pacheco et al., 2020), including publics accustomed to, and willing to cooperate with, pandemic control measures-beginning with the most basic such as masking (e.g., Marmino \& Vandenberg, 2021; Nguyen, 2020). It is also worth noting that many Asian states seem to be able to count on higher levels of public trust (Kleinfeld, 2020), facilitating the deployment of these forms of "infrastructural power". ${ }^{1}$

While responses to the pandemic may promise the further decline of some Eurocentric colonial hierarchies, and may auger additional challenges for liberal hegemony, what might be most notable is how little seems to have changed, despite states of exception, the profound transformations of daily life, millions of deaths, and widespread impoverishment. While many desperately await a return to normal, we should take cognizance of the fact that the "normal" state of global affairs was entirely unsustainable. The rapacious exploitation of the planet has now reaching its limits, provoking a steadily-increasing tempo of ecological catastrophes, among the most dramatic of which were the fires that swept California, Australia, Amazonia, and South America's wetlands. Less widely noticed, at least before the end of 2019, was that the steady stream of new infectious diseases making headlines (SARS, MERS, "bird flu," "swine flu", etc.) represented an overall increase in the historical rate of zoonotic (animal-to-human) pathogenic transfer (see e.g., Smith et al., 2014); making the emergence of a pandemic like COVID-19 entirely predictable for those who study the question (Malm, 2020; Quammen, 2012). This suggests, grimly, that pandemics like this one-or worse-will become an increasingly regular feature of late capitalist life, as the drive to endless accumulation pushes causes further disruption in zones of high biological diversity (Jones, Betson, \& Pfeiffer, 2017; Malm, 2020).

The seriousness of this prognosis hardly needs stressing for the traumatized publics of 2021. By the end of 2020, the COVID-19 pandemic had already claimed more than a million lives. It is impossible to know how many more will die before vaccines reach the bulk of the world's population. Tens of millions more have lost their livelihoods or sunk deeper into poverty. The historical moment in which it seemed possible to say that humanity-or at least it's wealthiest tierhad "conquered" infectious disease is now definitively over (Malm, 2020). While we have certainly developed capacities to control the spread of pathogens through antibiotics, antivirals, and vaccines, we are also facing an accelerated pace of zoonotic spillover-the transfer from humans to animals-and a parallel climate crisis.

As humanity grapples with an expanding climate emergency, the COVID-19 pandemic may offer insight into the ways that this existential crisis might be addressed. Rather than embrace globally-coordinated action, what we have witnessed is a fragmented response-even within particular nation-states, such as the United States-that have undermined humanity's capacity to successfully respond to a crisis that transcends any single society. Instead, we have seen systematic denial of the severity of the crisis in many cases, with a populist critique of science mobilized to undermine those who attempt to enact a proactive response to the pandemic. Most recently, the expansion of populist and authoritarian political tendencies has been accompanied by vaccine nationalism, or the hoarding of essential medicines in the face of a lethal pandemic. Xenophobic sentiment, othering, and hate crimes have arisen in response to these populist and nationalist tropes, with anti-Asian violence in the United States one entailment of these despicable characterizations. Indeed, if the COVID-19 pandemic is a precursor of what is to come as the climate crisis worsens, we have reasons to be gravely concerned.

However, the pandemic has also been accompanied by dynamics that carry with them the possibility of new and different responses to the looming crises faced by humanity. The callous indifference towards death, which manifested as the active promotion of "acceptable" deaths in some cases, has been countered by a politics that seeks to upend the valorization of economy over society, of profit over people. New forms of solidarity and community-based initiatives have sprung up in response to the pandemic, with alliances of non-state organizations taking on the necessary task of providing support to those in need, filling the social welfare capacities abandoned by the state during what increasing looks like, for many societies across the global south, a longue durée of neoliberal austerity-while, at the same time, state-sponsored social welfare seems to have increased in legitimacy in many contexts Transnational campaigns for vaccine access continue to expand, challenging global patent regimes and monopoly pricing rights for life-saving

1 Michael Mann (1984) has argued that state "infrastructural power”, as opposed to "despotic power”, works through the cooperation of "civil society"; although the distinction is in many ways a crude one, it is a useful starting point for parsing the difference between publiclycoordinated collective initiatives and the arbitrary or despotic exercise of centralized power. Orientalist tropes in the West, of course, tend to represent Asian polities as despotic, obscuring the many forms by which consent to, and cooperation with, state power is secured. Studies of Vietnam's and Taiwan's responses interestingly highlight a high degree of transparency in the response to COVID-19 (Marmino \& Vandenberg, 2021; Nguyen, 2020). 
medicines, including the COVID-19 vaccines, while raising critiques of the valorization of private profit over human life. These initiatives highlight that the current historical moment carries within it divergent possibilities for addressing future crises. One can only hope that lessons are learned from the politicized responses to the COVID-19 pandemic, which have caused needless and preventable deaths that now number in the millions.

Acknowledgments: First, we would like to acknowledge our colleagues who supported the development of this project through their work as peer-reviewers, whose input played a central role in refining the contributions included in this volume. We offer our deepest thanks to those who provided this essential feedback, which was undertaken during the pandemic, when many were grappling with increased workloads both at work and at home. We would also like to offer our thanks to the Association for the Anthropology of Policy, which sponsored a panel of the same title for the 2020 annual meeting of the American Anthropological Association. Finally, our thanks to the editors of Open Anthropological Research for their invitation to contribute to their journal and for their patience as we developed this project amid the constraints imposed by the pandemic.

Conflict of Interest: Authors state no conflict of interest.

\section{References}

Adams, V., \& Nading, A. (2020). Medical Anthropology in the Time of COVID-19. Medical Anthropology Quarterly, 34(4), 461-466. https:// doi.org/10.1111/maq.12624 PMID:33289159

Agamben, G. (2020, March 28). Normalising the state of exception under the Covid-19 epidemic. Non.Copyriot.Com. https://non.copyriot. com/giorgio-agamben-normalising-the-state-of-exception-under-the-covid-19-epidemic/

Apuzzo, M., Gebrekidan, S., \& Pronczuk, M. (2021, March 20). Where Europe Went Wrong in Its Vaccine Rollout, and Why. The New York Times. https://www.nytimes.com/2021/03/20/world/europe/europe-vaccine-rollout-astrazeneca.html

Buckley, J. (2021, January 22). Vietnam's Pandemic. Sidecar/New Left Review. https://newleftreview.org/sidecar/posts/vietnams-pandemic

Farmer, P. (1999). Pathologies of power: Rethinking health and human rights. American Journal of Public Health, 89(10), 1486-1496. https:// doi.org/10.2105/AJPH.89.10.1486 PMID:10511828

Gandesha, S. (2020). The Specter of the 1930s. In J. Rayner, S. Falls, G. Souvlis, \& T. Nelms (Eds.), Back to the 30s? Recurring Crises of Capitalism, Liberalism, and Democracy (pp. 37-53). Palgrave Macmillan. https://doi.org/10.1007/978-3-030-41586-0_2

Jones, B. A., Betson, M., \& Pfeiffer, D. U. (2017). Eco-social processes influencing infectious disease emergence and spread. Parasitology, 144(1), 26-36. https://doi.org/10.1017/S0031182016001414 PMID:27609615

Kleinfeld, R. (2020, March 31). Do Authoritarian or Democratic Countries Handle Pandemics Better? Carnegie Endowment for International Peace. https://carnegieendowment.org/2020/03/31/do-authoritarian-or-democratic-countries-handle-pandemics-better-pub-81404

Lynteris, C. (2020, March 6). COVID-19 Forum: Introduction. Somatosphere. http://somatosphere.net/2020/covid-19-forum:-introduction. $\mathrm{html} /$

Malm, A. (2020). Corona, Climate, Chronic Emergency: War Communism in the Twenty-First Century. Verso.

Mann, M. (1984). The autonomous power of the state: Its origins, mechanisms and results. European Journal of Sociology/Archives Européennes de Sociologie/Europäisches Archiv Für Soziologie, 25(2), 185-213.

Marmino, M., \& Vandenberg, L. (2021, January 25). The Role of Political Culture in Taiwan's COVID-19 Success. The Diplomat. https:// thediplomat.com/2021/01/the-role-of-political-culture-in-taiwans-covid-19-success/

Maskovsky, J., \& Bjork-James, S. (2019). Introduction. In J. Maskovsky \& S. Bjork-James (Eds.), Beyond Populism: Angry Politics and the Twilight of Neoliberalism. West Virginia University Press.

Mazzucato, M. (2020, December 28). Covid exposes capitalism's flaws. Financial Times. https://www.ft.com/content/9e7b2630-2f67-4923aa76-0f240a80a9b3

Nguyen, S. (2020). Vietnam's Pandemic Success is a Lesson for the World. Global Asia, 15(3), 43-48.

Pacheco Pardo, R., Avendano Pabon, M., Chen, X., Jing, B., Lee, J., Ting, J., Matsuda, T., \& Yu, K. (2020). Preventing the Next Pandemic: Lessons from East Asia. King's College of London Faculty of Social Science and Public Policy. https://www.kcl.ac.uk/eis/assets/ kdefsresearchreport2020-a4-proof2-singlepage.pdf

Quammen, D. (2012). Spillover: Animal Infections and the Next Human Pandemic. W. W. Norton.

Rayner, J., Falls, S., Nelms, T., \& Souvlis, G. (2020). Introduction: Back to the 30s? In J. Rayner, S. Falls, G. Souvlis, \& T. Nelms (Eds.), Back to the 30s? Recurring Crises of Capitalism, Liberalism, and Democracy (pp. 1-33). Palgrave Macmillan. https://doi.org/10.1007/978-3030-41586-0_1

Roy, A. (2020, April 3). The Pandemic is a Portal. Financial Times. Accessed on April 5, 2020 at: https://www.ft.com/content/10d8f5e8-74eb11ea-95fe-fcd274e920ca 
Smith, K. F., Goldberg, M., Rosenthal, S., Carlson, L., Chen, J., Chen, C., \& Ramachandran, S. (2014). Global rise in human infectious disease outbreaks. Journal of the Royal Society, Interface, 11(101), 20140950. https://doi.org/10.1098/rsif.2014.0950 PMID:25401184

Webb, M. A. P. (2019). School Optimism: Fast Life and Slow Debt in the Financialized University (PhD Dissertation, CUNY, New York). Retrieved from CUNY Academic Works https://academicworks.cuny.edu/gc_etds/3130/

Žižek, S. (2020). Pandemic!: COVID-19 Shakes the World. Polity.

Zuboff, S. (2019). The Age of Surveillance Capitalism: The Fight for a Human Future at the New Frontier of Power. Hatchette. 